University of Nebraska - Lincoln

DigitalCommons@University of Nebraska - Lincoln

\title{
What do farmers' weed control decisions imply about glyphosate resistance? Evidence from surveys of US corn fields
}

Seth J. Wechsler

USDA - Economic Research Service, seth.wechsler@ers.usda.gov

Jonathan R. McFadden

USDA - Economic Research Service, jonathan.mcfadden@ers.usda.gov

David J. Smith

USDA - Economic Research Service

Follow this and additional works at: https://digitalcommons.unl.edu/usdaarsfacpub

Wechsler, Seth J.; McFadden, Jonathan R.; and Smith, David J., "What do farmers' weed control decisions imply about glyphosate resistance? Evidence from surveys of US corn fields" (2017). Publications from USDA-ARS / UNL Faculty. 1785.

https://digitalcommons.unl.edu/usdaarsfacpub/1785

This Article is brought to you for free and open access by the U.S. Department of Agriculture: Agricultural Research Service, Lincoln, Nebraska at DigitalCommons@University of Nebraska - Lincoln. It has been accepted for inclusion in Publications from USDA-ARS / UNL Faculty by an authorized administrator of DigitalCommons@University of Nebraska - Lincoln. 


\title{
What do farmers' weed control decisions imply about glyphosate resistance? Evidence from surveys of US corn fields
}

\author{
Seth J Wechsler, ${ }^{*} \odot$ Jonathan R McFadden and David J Smith ${ }^{\dagger}$
}

\begin{abstract}
BACKGROUND: The first case of glyphosate-resistant weeds in the United States was documented in 1998, 2 years after the commercialization of genetically engineered herbicide-resistant (HR) corn and soybeans. Currently, over 15 glyphosate-resistant weed species affect US crop production areas. These weeds have the potential to reduce yields, increase costs, and lower farm profitability. The objective of our study is to develop a behavioral model of farmers' weed management decisions and use it to analyze weed resistance to glyphosate in US corn farms.
\end{abstract}

RESULTS: On average, we find that weed control increased US corn yields by $3700 \mathrm{~kg} \mathrm{ha}^{-1}$ (worth approximately $\$$ US $255 \mathrm{ha}^{-1}$ ) in 2005 and $3500 \mathrm{~kg} \mathrm{ha}^{-1}$ (worth approximately \$US $575 \mathrm{ha}^{-1}$ ) in 2010 . If glyphosate resistant weeds were absent, glyphosate killed approximately $99 \%$ of weeds, on average, when applied at the label rate in HR production systems. Average control was dramatically lower in states where glyphosate resistance was widespread.

CONCLUSION: We find that glyphosate resistance had a significant impact on weed control costs and corn yields of US farmers in 2005 and 2010.

Published 2017. This article is a U.S. Government work and is in the public domain in the USA.

Supporting information may be found in the online version of this article.

Keywords: glyphosate resistance; genetically enginereed crops; herbicide resistance; corn; damage abatement; non-linear full information maximum likelihood; control functions

\section{INTRODUCTION}

Prior to the development of selective herbicides, post-emergent weed control was often costly and time consuming. In the early 1940s, the active ingredient 2,4-D was patented. ${ }^{1}$ The post-war commercialization of this selective herbicide transformed domestic weed management practices and ushered in the modern era of chemical weed control.

The herbicide glyphosate was patented in 1970. ${ }^{2}$ Unlike 2,4-D, glyphosate was non-selective. Therefore, it was primarily used in pre-emergent applications. This changed in 1996 when the first genetically engineered herbicide-resistant (HR) crops were commercialized. These crops simplified the use of non-selective herbicides such as glyphosate in post-emergent applications.

Initially, demand for herbicide-resistant corn seeds was relatively low. Fewer than $10 \%$ of US corn acres were planted with HR seeds in $2000 .{ }^{3}$ However, adoption rates increased rapidly in the early twenty-first century. By 2010, almost three out of every four domestic corn acres were planted with herbicide-resistant seeds.

The rapid adoption of HR crops dramatically increased farmers' post-emergent glyphosate use. Although glyphosate was applied to only $4 \%$ of corn acres in 1996, it was applied to approximately three out of four acres in $2010 .^{4}$ Unfortunately, farmers' reliance on glyphosate led to the development of glyphosate-resistant weed populations. ${ }^{5}$ As of 2015 , over 15 glyphosate-resistant weed species had been identified in the United States. ${ }^{6}$

Although it is possible to study the impacts of glyphosate resistance at a local level using field trials, it is difficult to quantify these impacts at a regional or national level because gathering detailed information about weed populations is expensive and logistically complicated. This article exploits the fact that resistance tends to induce changes in farmers' behavior. By assuming that farmers are primarily interested in maximizing profits, we are able to derive expressions for the optimal level of pre-emergent and post-emergent weed control. We estimate the behavioral model by analyzing repeated cross-sections of nationally representative data from the USDA's Agricultural Resource Management Survey

* Correspondence to: SJ Wechsler, US Department of Agriculture - Economic Research Service, Washington, DC, USA.E-mail: seth.wechsler@ers.usda.gov

Correction added on 18 August 2017, after first online publication: the name of the $14^{\text {th }}$ row of Table 4 has been corrected to "HR seed adoption $\times$ number of weeds resistant to glyphosate in state" in this version of the article.

$\dagger$ The views expressed are those of the authors and should not be attributed to the Economic Research Service or the USDA.

US Department of Agriculture - Economic Research Service, Washington, DC, USA 
(ARMS). The results of this analysis allow us to infer how resistance affects weed control, crop damage, and yield losses.

\subsection{Structural models of pest control}

In agricultural economics, a widely held assumption is that crop production (or yield) increases with increased input use, though at a diminishing rate. This assumption makes sense for inputs such as fertilizers, which directly increase yields. However, it makes less sense for inputs such as herbicides, which prevent damages caused by weeds. Lichtenberg and Zilberman ${ }^{7}$ developed a structural framework that accounts for the fact that pesticides only impact yields when pests are present. Specifically, they modeled yields such that $Y=Y G\left(x_{p}\right)$, where $Y$ represents yields when pests are absent, $G \in(0,1)$ is abatement (the percentage of $Y$ not damaged by pest infestations), and $x_{p}$ is a measure of pesticide use.

Lichtenberg and Zilberman's damage control framework has a number of advantages. First, it produces intuitive estimates of yield losses, crop damage, and the severity of pest infestations. Second, and arguably more importantly, it predicts that resistance increases pesticide use. Evidence suggests that this is how farmers tend to behave in the field. ${ }^{8}$

Empirical tests of damage control models have produced favorable results. Saha et al. ${ }^{9}$ and Chambers and Lichtenberg ${ }^{10}$ found that damage abatement models outperformed more conventional methods of modelling yields. Chambers and Tzouvelekas ${ }^{11}$ demonstrated that damage control models could accurately estimate the dynamics of pest populations.

\subsection{Previous studies of HR crops}

Few studies have used damage control models to analyze the domestic impacts of HR crops. However, the impacts of HR seed use have been studied using a variety of reduced-form approaches. For instance, Fernandez-Cornejo et al. ${ }^{12}$ analyzed the impacts of HR soybean adoption using data from USDA's 1997 ARMS. They found that planting HR soybeans had a small, statistically significant impact on yields, but an insignificant impact on profits. Fernandez-Cornejo et al. ${ }^{13}$ employed a similar approach using ARMS data collected in 2000. They found that HR soybean adoption increased off-farm income, but not on-farm income. Nolan and Santos ${ }^{14}$ estimated a reduced-form model of corn yields using data from US field trials. They found limited evidence that corn with HR traits had higher yields than corn produced from conventional seeds.

To our knowledge, this is the first article to use the damage control framework to model the uncertainty induced by the timing of corn farmers' weed control decisions. However, our primary contribution is to quantify the extent to which glyphosate resistance affected US corn yields in 2005 and 2010. Although field tests can indicate whether resistance has developed in field-level populations, our approach can be used to analyze large study regions. It can be implemented wherever data about prices, field characteristics, and farmers' production practices are collected.

\section{MATERIALS AND METHODS}

\subsection{A behavioral model of farmers' weed control decisions}

We assume that weeds can be controlled with tillage, cultivation, or herbicide applications. Selective herbicides can be applied by any farmer, before or after crop emergence. Although any non-selective herbicide (such as glyphosate) can be applied prior to crop emergence, glyphosate-resistant seeds can survive post-emergent glyphosate applications.

In the first stage of our model $(t=1)$, farmers choose whether to plant glyphosate-resistant seeds, the amount of pre-emergent herbicide to apply, and how much to till. In this stage there is uncertainty about future growing conditions. In the second stage $(t=2)$, farmers observe growing conditions, choose the amount of post-emergent herbicide to apply, and how much to cultivate.

We assume that farmers' primary goal is to maximize profits $(\pi)$, which we model by assuming that

$$
\begin{gathered}
\pi=P Y-p_{\mathrm{GR}} G R-\sum_{t} \sum_{x} p_{t}^{x} X_{t}^{x} \\
t \in\{1,2\} \\
x \in\{\mathrm{H}, \mathrm{T}\}
\end{gathered}
$$

where $P$ is the price of corn, $Y$ represents yields, $p_{\mathrm{GR}}$ is the price of glyphosate-resistant seeds, $X_{1}{ }^{\top}$ reflects the intensity of tillage operations, $X_{2}{ }^{\top}$ reflects the intensity of cultivation, $X_{1}{ }^{H}$ reflects pre-emergent herbicide use, $X_{2}{ }^{H}$ reflects post-emergent herbicide use, $G R$ is an indicator for glyphosate-resistant seed use, and $p_{t}{ }^{x}$ is the price of the weed-controlling input $X_{t}^{X}$.

We assume that farmers maximize expected profits by choosing the amount of each weed-controlling input to apply. These weed control decisions do not affect input or output prices. Therefore, the farmer's profit maximization problem is

$$
\begin{gathered}
\max _{X_{t}^{\mathrm{x}} \geq 0, G R \in\{0,1\}} \mathrm{E}\left[P Y-p_{\mathrm{GR}} G R-\sum_{t} \sum_{x} p_{t}^{x} X_{t}^{\mathrm{x}}\right] \\
\text { s.t. } Y=Y G\left(G R, X_{1}^{\top}, X_{1}^{\mathrm{H}}, X_{2}^{\top}, X_{2}^{\mathrm{H}}, W_{1}, W_{2}\right) \exp (v)
\end{gathered}
$$

where $Y$ represents weed-free yields, $G \in(0,1)$ is abatement (the percentage of $Y$ not damaged by weeds), $W_{1}$ is the size of the uncontrolled weed population in the pre-emergent stage, $W_{2}$ is the size of the uncontrolled weed population in the post-emergent stage, and $v$ is a realization of the random variable $\varepsilon$ (epsilon enters the expected yield function in the pre-emergent stage). Uncertainty enters the maximization problem because farmers do not have information about future growing conditions at planting time. Consequently, farmers must make their pre-emergent weed control decisions based on expectations about yields and post-emergent weed control.

In order to derive expressions for the optimal level of pre-emergent and post-emergent weed control, the abatement function must be specified. Building on Fox and Weersink, ${ }^{15}$ we assume that the abatement function is multiplicatively separable such that $G=G_{1} G_{2}$ and model abatement in stage $t$ as $G_{t}=1-D_{t}\left(W_{t}, C_{t}\right)$, where $D_{t}$ represents crop damage (the percentage of $Y$ damaged by weed infestations) and $C_{t}$ represents weed control (the percentage of the weed population killed by herbicides, tillage and/or cultivation). Weed control is increasing in the amount of herbicide applied, the intensity of tillage operations, and the intensity of cultivation practices. Crop damage is decreasing in the amount of weed control and increasing in the size of the weed population.

Both $C_{t}$ and $D_{t}$ are specified using exponential cumulative distribution functions. The weed control functions are

$$
C_{t}=1-\exp \left(\sum_{x}-c_{t}^{x} X_{t}^{x}\right)
$$


(a)

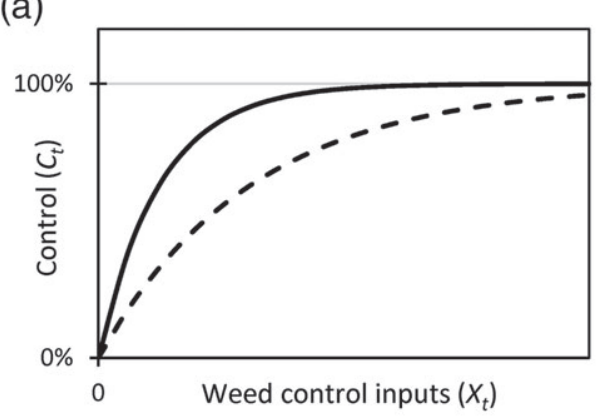

(b)

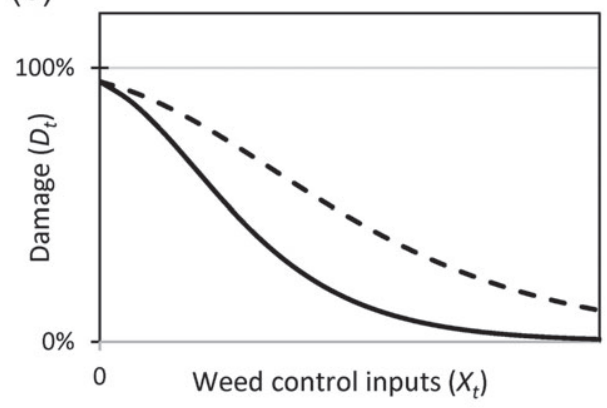

(d)

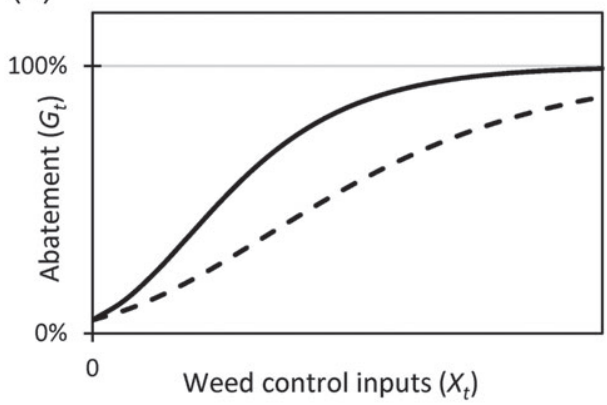

(c)

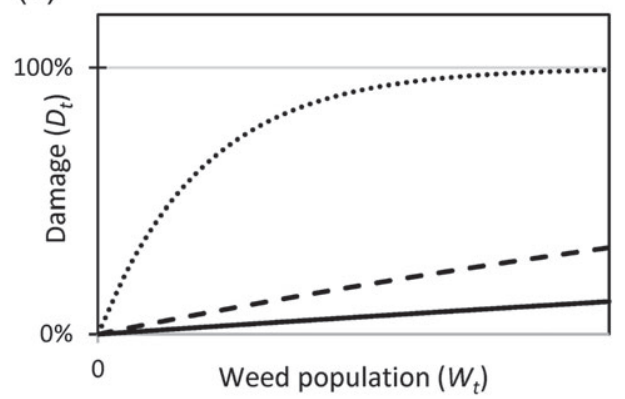

(e)

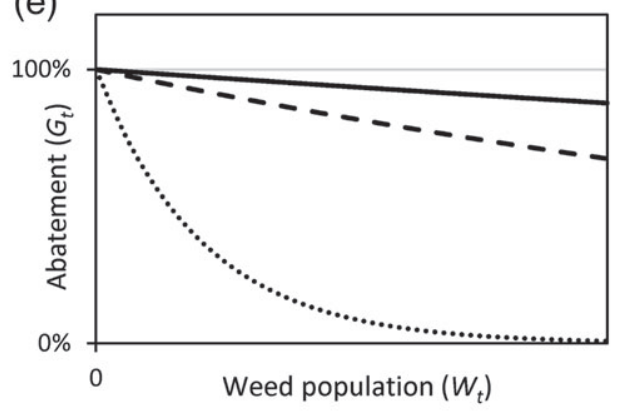

Figure 1. Graphs of control, damage and relative yields as a function of weed control inputs (with and without resistance) and weed population.

where $c_{t}^{x}$ is a 'weed control' parameter (Fig. 1a). Conceptually, $c$ reflects the efficacy of an input. If $c$ is large, the input is effective. As will be discussed in the following section, $c$ is affected by a variety of field-level conditions and environmental factors. For instance, HR seed use may increase the efficacy of post-emergent herbicides, but resistance can reduce it.

The damage functions are

$$
D_{t}=1-\exp \left[-d_{t} W_{t}\left(1-C_{t}\right)\right]
$$

where $d_{t}$ is a 'damage' parameter (Figs $1 \mathrm{~b}$ and c). Conceptually, $d$ reflects the destructiveness of weeds at different points during the growing season. Larger values of $d$ correspond to larger crop damage.

This specification of the abatement function implies that yields are

$$
\begin{aligned}
Y & =Y \exp (v) G \\
& =Y \exp (v) \prod_{t=1}^{2} \exp \left[-d_{t} W_{t} \exp \left(\sum_{x}-c_{t}^{x} X_{t}^{x}\right)\right] .
\end{aligned}
$$

Equation 5 closely resembles the Gompertz model, which has been used by weed scientists to estimate the relationship between yields and weed-free days. ${ }^{16,17}$ Notice that yields are increasing in the amount of weed control and decreasing in the size of the weed population (Figs $1 \mathrm{~d}$ and e).

We are able to derive expressions for the optimal level of pre-emergent herbicide use, post-emergent herbicide use, tillage, and cultivation by solving the farmer's expected profit maximization problem. We could estimate these non-linear functions simultaneously, but doing so would be technically challenging (in part because many farmers do not use all four inputs during the same growing season). Fortunately, the results of the behavioral model can be used to simplify the empirical analysis.

If a farmer is maximizing profits, an increase in one pre-emergent input must provide the same increase in profits as an increase in every other pre-emergent input. If it did not, the farmer could benefit by increasing the use of one input while reducing the use of the other. The same logic applies to post-emergent input use. This implies that $p_{t}{ }^{\top} / c_{t}{ }^{\top}=p_{t}{ }^{\mathrm{H}} / c_{t}{ }^{\mathrm{H}}$ if both tillage and herbicides are used in stage $t$.

We use this theoretical result to derive expressions for the optimal level of pre-emergent and post-emergent weed control expenditures (see supporting information Appendix A). The 
Table 1. Summary statistics ${ }^{\mathrm{a}}$

\begin{tabular}{|c|c|c|}
\hline & Mean & SD \\
\hline \multicolumn{3}{|l|}{ Endogenous variables } \\
\hline $\begin{array}{l}\text { Expenditures on pre-emergent weed } \\
\text { control }\left(\$ \cup S \mathrm{ha}^{-1}\right)\end{array}$ & 23.00 & 21.96 \\
\hline $\begin{array}{l}\text { Expenditures on post-emergent weed } \\
\text { control }\left(\$ \cup S \mathrm{ha}^{-1}\right)\end{array}$ & 25.51 & 23.70 \\
\hline Yield goal $\left(\mathrm{kg} \mathrm{ha}^{-1}\right)$ & 12881 & 2313 \\
\hline Yield $\left(\mathrm{kg} \mathrm{ha}^{-1}\right)$ & 11908 & 3178 \\
\hline Herbicide-resistant (HR) seed use (\%) & 48 & 50 \\
\hline \multicolumn{3}{|l|}{ Exogenous variables } \\
\hline $\begin{array}{l}\text { Herbicide-resistant seed price ratio (HR to } \\
\text { conventional) }\end{array}$ & 1.28 & 0.12 \\
\hline Glyphosate price (\$US kg-1) & 15.47 & 5.23 \\
\hline Corn price $\left(\$ \mathrm{US} \mathrm{kg}^{-1}\right)$ & 0.12 & 0.05 \\
\hline Diesel price $\left(\$ \cup \mathrm{S} \mathrm{L}^{-1}\right)$ & 0.62 & 0.05 \\
\hline $\begin{array}{l}\text { Non-glyphosate post-emergent herbicide } \\
\text { price (\$US adj. } \mathrm{kg}^{-1} \text { ) }\end{array}$ & 27.13 & 7.19 \\
\hline Corn area (ha) & 223.03 & 9.06 \\
\hline NCCPI corn and soybean index & 0.50 & 0.17 \\
\hline Highly erodible soil indicator $(0-1)$ & 0.20 & 0.40 \\
\hline Soil pH (scale on $0-14$ ) & 6.22 & 0.42 \\
\hline Soil organic matter (\%) & 3.53 & 1.54 \\
\hline $\begin{array}{l}\text { Deviation from normal February } \\
\text { precipitation }(\mathrm{cm})\end{array}$ & -4.27 & 37.43 \\
\hline $\begin{array}{l}\text { Cumulative growing season precipitation, } \\
20 \text { year average }(\mathrm{cm})\end{array}$ & 16.5 & 1.79 \\
\hline $\begin{array}{l}\text { Cumulative growing degree days, } 20 \text { year } \\
\text { average (GDDs) }\end{array}$ & 1471 & 162.35 \\
\hline $\begin{array}{l}\text { Number of state-level weeds resistant to } \\
\text { glyphosate in corn }\end{array}$ & 0.53 & 0.99 \\
\hline $\begin{array}{l}\text { Number of state-level weeds resistant to } \\
\text { herbicides, previous year }\end{array}$ & 12.76 & 5.40 \\
\hline Heartland (\%) & 68 & 47 \\
\hline Northern Crescent (\%) & 20 & 40 \\
\hline Northern Great Plains (\%) & 02 & 15 \\
\hline Prairie Gateway (\%) & 09 & 29 \\
\hline Eastern Uplands (\%) & 01 & 12 \\
\hline Year 2010 (\%) & 48 & 50 \\
\hline Number of observations & \multicolumn{2}{|c|}{2397} \\
\hline $\begin{array}{l}\text { a All prices and expenditures have been de } \\
\text { ensure representativeness of US corn field } \\
\text { using NASS' base expansion factor. }\end{array}$ & 2010 & $\begin{array}{l}\text { ars. To } \\
\text { ghted }\end{array}$ \\
\hline
\end{tabular}

optimal level of pre-emergent expenditures is

$$
\operatorname{Cost}_{1} \equiv \sum_{x} p_{1}^{x} X_{1}^{x}=\frac{p_{1}}{c_{1}}\left[\ln \left(d_{1} W_{1}\right)+\ln \left(\frac{P \mathrm{E}[Y]}{\frac{p_{1}}{c_{1}}-\frac{p_{2}}{c_{2}}}\right)\right] .
$$

The optimal level of expenditures on post-emergent weed control is

$$
\operatorname{Cost}_{2} \equiv \sum_{x} p_{2}^{x} X_{2}^{x}=\frac{p_{2}}{c_{2}}\left[\ln \left(d_{2} W_{2}\right)+\ln \left(\frac{c_{2} P Y}{p_{2}}\right)\right] .
$$

These expressions provide valuable insight into how changes in the explanatory variables and model parameters affect farmers' demand for weed control. Equation 6 suggests that expenditures on pre-emergent weed control increase with the size of the pre-emergent weed population, the destructiveness of this population, the price of corn, the price of post-emergent weed control, and expected yields. Decreases in the efficacy of post-emergent control also increase pre-emergent expenditures.

Equation 7 suggests that expenditures on post-emergent weed control increase with the size of the post-emergent weed population, the destructiveness of this population, corn prices, and yields. Because we assumed that uncontrolled weeds grow between stage 1 and stage 2 such that $W_{2}=W_{1}\left[1-C_{1}\right] \exp (r)$, where $r$ is the growth rate, the optimal level of post-emergent weed control also depends on the level of pre-emergent expenditures.

Having derived equations 6 and 7, it is possible to model corn yields in terms of optimal pre-emergent and post-emergent expenditures on weed control:

$$
Y=Y \exp (v) \prod_{t=1}^{2} \exp \left[-d_{t} W_{t} \exp \left(-\frac{c_{t}}{p_{t}} \text { Cost }_{t}\right)\right] \text {. }
$$

\subsection{Empirical approach}

We recover the model parameters by estimating the following system of non-linear equations:

$$
\begin{aligned}
\operatorname{Cost}_{1}= & \frac{p_{1}}{c_{1}}\left[\ln \left(d_{1} W_{1}\right)+\ln (P E[Y])-\ln \left(\frac{p_{1}}{c_{1}}-\frac{p_{2}^{j}}{c_{2}^{j}}\right)\right]+e_{1} \\
\operatorname{Cost}_{2}= & \frac{p_{2}^{j}}{c_{2}^{j}}\left[\ln \left(d_{2} W_{1}\right)+r-\frac{c_{1}}{p_{1}} \operatorname{Cost}_{1}+\ln \left(\frac{c_{2}^{j} P Y}{p_{2}^{j}}\right)\right]+e_{2} \\
\ln (Y)= & \ln (Y)-d_{1} W_{1} \exp \left(-\frac{c_{1}}{p_{1}} \operatorname{Cost}_{1}\right) \\
& -d_{2} W_{1} \exp \left(r-\frac{c_{1}}{p_{1}} \operatorname{Cost}_{1}-\frac{c_{2}^{j}}{p_{2}^{j}} \operatorname{Cost}_{2}\right)+v
\end{aligned}
$$

where $j \in\{g, n g\}, g$ reflects glyphosate use, $n g$ reflects the use of herbicides other than glyphosate, and $e_{\mathrm{t}}$ are appended error terms. Crucially, the form of equation 9 depends on whether glyphosate is used in a post-emergent application. This allows us to estimate the efficacy of post-emergent weed control for: 1) fields where glyphosate is used in post-emergent weed control systems $\left(c_{2}{ }^{g}\right)$ and 2) fields where glyphosate is not used in post-emergent weed control systems $\left(c_{2}^{n g}\right)$. We assume that $\left(e_{1}, e_{2}, v\right)$ has a joint normal distribution. Therefore, there is a closed-form expression for the log-likelihood function corresponding to equation $9 .{ }^{18,19} \mathrm{We}$ estimate the system of equations using non-linear full information maximum likelihood. As discussed in supporting information Appendix $B$, the form of the likelihood function also depends on whether an observation is censored.

We assume that a variety of factors influence the efficacy of weed control. For example, we expect the efficacy of post-emergent glyphosate applications to be lower on fields where glyphosate resistant weeds are present. We expect soil characteristics such as $\mathrm{pH}$ and organic matter content to influence the efficacy of pre-emergent weed control $\left(c_{1}\right)$ because pre-emergent herbicides tend to be applied to (or incorporated into) the soil. ${ }^{20}$ Therefore, we let

$$
\begin{aligned}
c_{1} & =\text { pre }_{0}+\text { pre }_{\mathrm{pH}} \mathrm{pH}+\text { pre }_{\mathrm{OM}} \mathrm{OM}+\text { pre }_{2010} \mathrm{I}_{2010} \\
c_{2}^{n g} & =\text { postng }_{0}+\text { postng }_{2010} \mathrm{I}_{2010}
\end{aligned}
$$



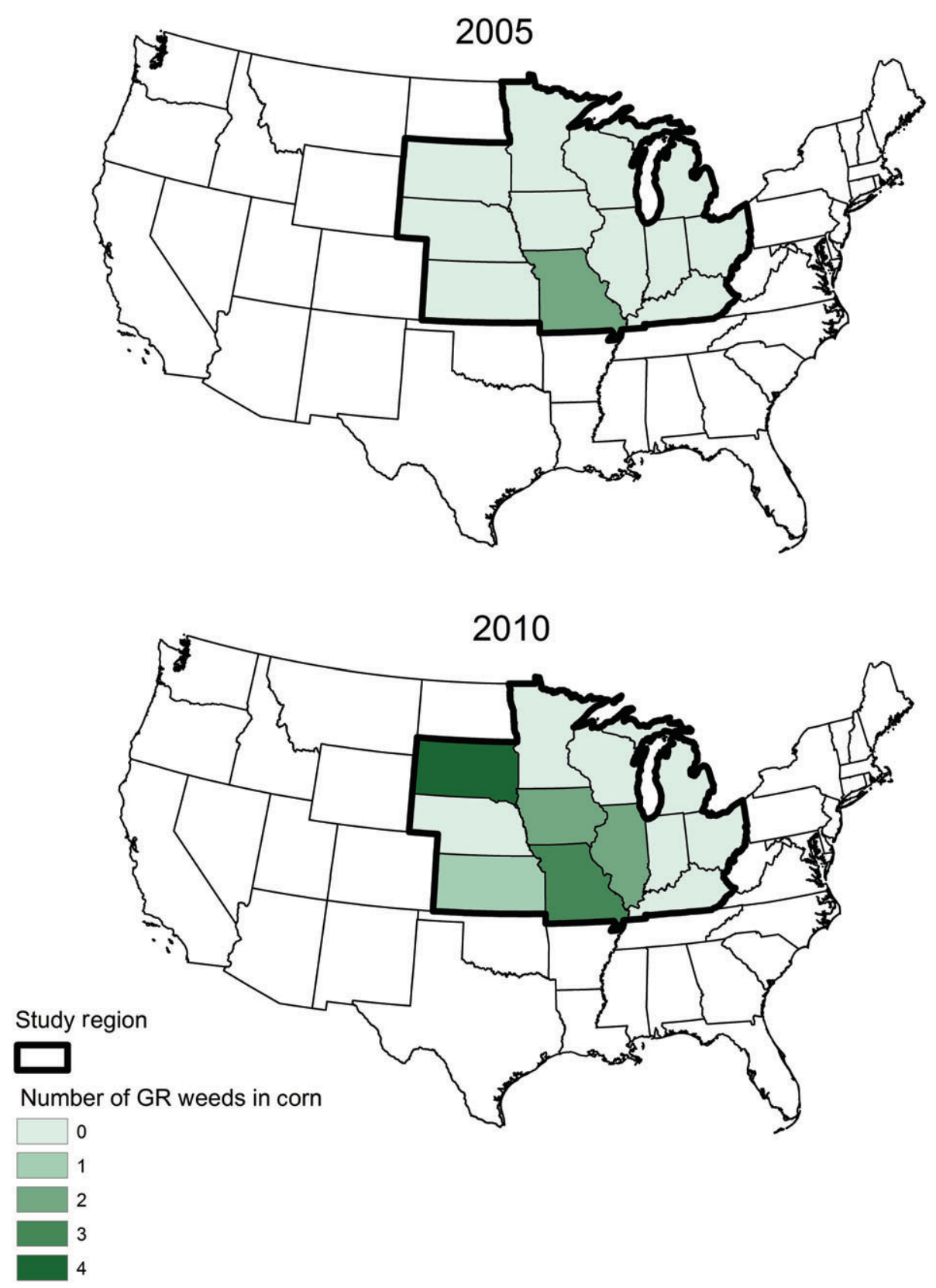

Figure 2. Number of glyphosate-resistant weeds in corn by state (source: ERS, using data from Heap). ${ }^{6}$

$$
\begin{aligned}
c_{2}^{g}= & \text { postg }_{0}+\text { postg }_{\mathrm{HR}} H R+\text { postg }_{\mathrm{R}} R \\
& + \text { postg }_{\mathrm{HRR}} H R \cdot R+\text { postg }_{2010} I_{2010}
\end{aligned}
$$

where $\mathrm{pH}$ is the soil $\mathrm{pH}, \mathrm{OM}$ is the percentage of soil organic matter, $I_{2010}$ is the indicator for 2010, $H R$ is an indicator of herbicide-resistant seed use, and $R$ is a state-level variable indicating the number of glyphosate-resistant weed species affecting corn production.

We assume that local environmental conditions influence weed-free yields. Therefore, we let $Y=\exp \left(\boldsymbol{\beta}_{Y}^{\prime} \boldsymbol{z}_{Y}\right)$, where $\boldsymbol{\beta}_{Y}$ is a vector of parameters and $\boldsymbol{z}_{\boldsymbol{Y}}$ is a vector of variables that capture variations in soil and climatic characteristics such as: the National Commodity Crop Productivity Index (NCCPI) for corn and soybeans, 20 year averages of cumulative precipitation and growing degree days, an indicator for the year 2010, and indicators for the
ERS-designated Farm Resource Regions (Heartlands, Northern Crescent, Northern Great Plains, and Prairie Gateway).

We do not have detailed field-level information about the size of weed populations. Therefore, we model weed pressure using the same variables we used to model weed-free yields. Specifically, we let $d_{t} W_{t}=\exp \left(\boldsymbol{\beta}_{\boldsymbol{W t}}^{\prime} \boldsymbol{z}_{\boldsymbol{W t}}\right)$, where $\boldsymbol{\beta}_{\boldsymbol{W t}}$ is a vector of parameters, and $\boldsymbol{z}_{W \boldsymbol{t}}$ is a vector of variables. Reparameterizing $d_{t} W_{t}$ and $Y$ using an exponential functional form ensures that weed-free yields, pre-emergent pest pressure, and post-emergent pest pressure are positive.

Our proxies for weed pressure are imperfect. Therefore, we consider the possibility that our results are biased by latent or omitted variables. This problem, called endogeneity, occurs if latent (or poorly-modeled) variables are correlated with both the dependent variable and other independent variables. Two of the variables in our model, yield goals and glyphosate-resistant 
Table 2. Sample means by post-emergent weed control strategy

\begin{tabular}{|c|c|c|c|}
\hline & Unit & 2005 & 2010 \\
\hline \multicolumn{4}{|c|}{ Fields with post-emergent glyphosate applications } \\
\hline Total pre-emergent expenditures & \$US ha-1 & 20.90 & 27.19 \\
\hline Total post-emergent expenditures & \$US ha-1 & 24.05 & 28.78 \\
\hline Expenditures on tillage & \$US ha ${ }^{-1}$ & 11.58 & 10.67 \\
\hline Expenditures on cultivation & \$US ha-1 & 1.43 & 0.64 \\
\hline Expenditures on pre-emergent herbicides ${ }^{a}$ & \$US ha-1 & 3.47 & 4.72 \\
\hline Expenditures on post-emergent herbicides ${ }^{a}$ & \$US ha ${ }^{-1}$ & 8.10 & 9.25 \\
\hline Yield goal & $\mathrm{kg} \mathrm{ha}^{-1}$ & 11960 & 13420 \\
\hline Yield & $\mathrm{kg} \mathrm{ha}^{-1}$ & 11457 & 12473 \\
\hline Herbicide-resistant seed users & $\%$ & 82 & 87 \\
\hline Number of glyphosate-resistant weeds & & 0.06 & 1.09 \\
\hline Number of observations & & 383 & 928 \\
\hline \multicolumn{4}{|c|}{ Fields without post-emergent glyphosate applications } \\
\hline Total pre-emergent expenditures & \$US ha-1 & 19.61 & 24.43 \\
\hline Total post-emergent expenditures & \$US ha-1 & 18.16 & 38.93 \\
\hline Expenditures on tillage & \$US ha-1 & 12.18 & 13.03 \\
\hline Expenditures on cultivation & \$US ha-1 & 2.48 & 0.80 \\
\hline Expenditures on pre-emergent herbicides ${ }^{a}$ & \$US ha-1 & 2.78 & 3.09 \\
\hline Expenditures on post-emergent herbicides ${ }^{a}$ & \$US ha-1 & 5.74 & 13.67 \\
\hline Yield goal & $\mathrm{kg} \mathrm{ha}^{-1}$ & 12741 & 12868 \\
\hline Yield & $\mathrm{kg} \mathrm{ha}^{-1}$ & 11585 & 11896 \\
\hline Herbicide-resistant seed users & $\%$ & 4 & 47 \\
\hline Number of glyphosate-resistant weeds & & 0.12 & 0.79 \\
\hline Number of observations & & 750 & 336 \\
\hline Total number of observations & & 1133 & 1264 \\
\hline
\end{tabular}

seed use, are likely to be correlated with weed pressure. For instance, HR seed use is more likely to be prevalent in locations where weed pressure is higher. If we systematically underestimate weed pressure, we could underestimate the impacts of glyphosate resistance. We test and account for endogeneity using a two-stage, control function-based approach. ${ }^{21-23}$

First, a probit model is used to analyze farmers' seed choices and an ordinary least squares regression is used to analyze yield goals (which serve as a proxy for expected yields). Next, the results from these regressions are used to estimate residuals, or control functions, which serve as proxies for latent variables that could bias our estimates. These control functions are included in $\boldsymbol{z}_{W}$, the vector of variables we use to model weed pressure.

To account for the two-stage nature of the endogeneity correction, and to ensure that our results are nationally representative, we used a bootstrapping procedure that resamples each field (with replacement) according to USDA's National Agricultural Statistics Service's (NASS) population expansion factor. ${ }^{21,24,25}$ Results are reported as means across 300 bootstrap samples.

Not all of the farmers in our sample controlled weeds both before and after crop emergence. Approximately $13 \%$ did not till or spray with pre-emergent herbicides. Roughly $7 \%$ did not cultivate or spray with post-emergent herbicides. There were seven fields in our 12-state study region where weeds were not controlled at all. We excluded these seven observations from our sample. The methods described in Yen and $\operatorname{Lin}^{26}$ were used to account for censoring in the pre-emergent and post-emergent cost functions.

\subsection{Data}

\subsubsection{Compilation and construction}

The ARMS is a cross-sectional, multiphase survey with a complex design. ${ }^{27}$ Phase II of this survey gathers field-level information about input use and production practices. Commodity-specific versions of the Phase II questionnaire are administered approximately once every five years. This study analyzes data from the 2005 and 2010 ARMS Phase II corn surveys.

The Phase II ARMS data contain information about seed choices, tillage decisions, and yield goals. The data also contain information about the timing of herbicide applications and the quantity of herbicide products applied. Although the ARMS survey collects information about a wide range of prices, the response rates for these questions tend to be low and highly-variable. Therefore, state-level estimates underlying the April release of NASS' Agricultural Prices report were used for herbicide active ingredient prices, corn prices, and diesel prices. We used the ratio of HR seed and conventional seed prices (calculated from responses to the ARMS survey) as a proxy for the real price of HR traits. Prices were adjusted to 2010 levels using the Bureau of Labor Statistic's Consumer Price Index.

Average quality-adjusted prices for glyphosate and herbicides other than glyphosate $\left(p^{j}\right)$ were estimated for every state and year. First, we converted every product application into a percentage of its label rate. Next, we multiplied these percentages by the label rate of a reference product (in this case, Roundup Original) and converted the pounds of product into pounds of active ingredient (we assumed a label rate of $1.12 \mathrm{~kg}$ glyphosate $\mathrm{ha}^{-1}$ ). We divided 


\begin{tabular}{|c|c|c|}
\hline Variable & HR seed use & In(Yield goals) \\
\hline \multicolumn{3}{|l|}{ Prices } \\
\hline $\ln (\mathrm{HT}$ seed price ratio) & -0.24 & 0.04 \\
\hline In(Glyphosate price) & 0.21 & $0.10^{* *}$ \\
\hline In(Corn price) & -1.11 & 0.15 \\
\hline Diesel price & $-1.42^{*}$ & $0.22^{* *}$ \\
\hline \multicolumn{3}{|l|}{ Area and growing conditions } \\
\hline $\ln ($ Corn area) & $0.08^{* * *}$ & $0.03^{* * *}$ \\
\hline NCCPI corn and soybean index & $-0.81^{* * *}$ & $0.28^{* * *}$ \\
\hline Highly erodible soil indicator & 0.12 & $-0.02^{* *}$ \\
\hline Soil pH & 0.72 & $0.64^{* * *}$ \\
\hline Soil organic matter & $0.72^{* *}$ & -0.01 \\
\hline $\begin{array}{l}\text { Deviation from normal February } \\
\text { precipitation }\end{array}$ & $0.01^{* * *}$ & $-0.002^{* * *}$ \\
\hline $\begin{array}{l}\text { Cumulative growing season } \\
\text { precipitation, } 20 \text { year average }\end{array}$ & -0.01 & $0.12^{* * *}$ \\
\hline $\begin{array}{l}\text { Cumulative growing degree days, } 20 \\
\text { year average }\end{array}$ & $-0.64^{*}$ & $-0.24^{* * *}$ \\
\hline $\begin{array}{l}\text { Number of state-level weeds resistant } \\
\text { to glyphosate in corn }\end{array}$ & 0.05 & $-0.01^{* *}$ \\
\hline $\begin{array}{l}\text { Number of state-level weeds resistant } \\
\text { to herbicides, previous year }\end{array}$ & -0.01 & -0.001 \\
\hline \multicolumn{3}{|l|}{$\begin{array}{l}\text { Farm resource region and year } \\
\text { indicators }\end{array}$} \\
\hline Heartland & -0.24 & $0.07^{* *}$ \\
\hline Northern Crescent & -0.46 & 0.03 \\
\hline Northern Great Plains & -0.06 & 0.04 \\
\hline Prairie Gateway & -0.23 & 0.02 \\
\hline Year 2010 & $3.14^{* * *}$ & -0.11 \\
\hline Intercept & 3.36 & $3.62^{* * *}$ \\
\hline$R^{2}$ & - & 0.27 \\
\hline AIC & 2543.9 & - \\
\hline Number of Observations & 2397 & 2397 \\
\hline
\end{tabular}

a Asterisks ***, and ${ }^{* * *}$ denote 10,5 , and $1 \%$ levels of significance. Parameter estimates are calculated as means across $B=300$ bootstrap samples. The standard errors are bootstrapped to maintain consistency with the set of bootstrapped standard errors for the main results. The AIC and $R^{2}$ values are calculated as means across the same set of bootstrap samples. The omitted region indicator is the Eastern Uplands area. Values of soil organic matter and soil pH have been divided by 10 , cumulative growing season precipitation has been divided by 10 , and cumulative growing degree days have been divided by 1000 .

state-level expenditures by state-level quality-adjusted quantities to get quality-adjusted prices.

We estimated machinery costs for herbicide application and tillage operations using detailed information about field operations from the ARMS survey. The cost of each operation was estimated using engineering models and prices obtained from NASS. ${ }^{28}$ We assumed that weed control costs were the sum of herbicide expenditures and machinery costs.

Data from Oregon State University's PRISM Climate Group were used to calculate county-level deviations from February precipitation levels, cumulative growing season precipitation, and cumulative growing degree days (GDDs). Ideally, GDDs should be calculated using daily data. Consequently, we aggregated daily data from annual PRISM records to develop cumulative growing season (May-August) GDDs. For 2005, twenty year norms were calculated by averaging cumlative growing season GDDs from 1985 to 2004. Cumulative growing season GDDs were averaged from 1990 to 2009 to get twenty year norms for observations recorded in 2010. A similar process was used to construct our measure of 20-year-averaged cumulative growing season precipitation.

County-level averages of the Natural Resources Conservation Service's (NRCS) National Commodity Crop Productivity Index (NCCPI) and soil characteristics from the Soil Survey Geographic Database (SSURGO) were also used in the analysis. NCCPI values from the Corn and Soybeans submodel were used as a proxy for exogenous growing conditions that influence a soil's inherent capacity to produce corn. ${ }^{29}$ The index ranges from 0 to 1 and aggregates a variety of weather attributes (e.g., frost-free days) and soil physical-chemical properties (e.g., soil type, depth to water table, available water capacity, cation exchange capacity, saturated hydraulic conductivity, etc.).

Apart from the NCCPI, we used three variables to capture the impacts of other important dimensions of soil quality that influence corn yields and farmers' weed control decisions. The first is a variable from the ARMS survey that indicates whether the NRCS has categorized any part of the field as 'highly erodible'. We expect highly-eroded fields to have lower corn yields. Farmers on HEL-designated fields may also tend to use mechanical means of weed control. The remaining two variables, soil $\mathrm{pH}$ and soil organic matter, are county averages from the SSURGO survey. Both of these variables affect herbicide persistence and efficacy.

Ideally, the ARMS data would include an exogenous measure of field-evolved weed resistance. Unfortunately, it does not. Therefore, we use state-level data from the International Survey of Herbicide-Resistant Weeds as a proxy for the intensity of weed resistance. ${ }^{6}$ Using variation in the number of glyphosate-resistant weed species reported by state and over time, we are able to estimate state-level impacts of glyphosate resistance.

\subsubsection{Descriptive statistics}

Table 1 summarizes the data used in this study. Adoption rates for herbicide-resistant corn seeds more than tripled from 2005 to 2010. There were also large changes in input and output prices over this time period. HR seed and corn prices more than doubled, while glyphosate prices dropped by nearly $50 \%$.

Generally, six glyphosate-resistant weed species were identified in corn fields over the course of our study period: common ragweed (Ambrosia artemisiifolia), giant ragweed (Ambrosia trifida), horseweed (Erigeron canadensis), kochia (Bassia scopari), palmer amaranth (Amaranthus palmeri), and tall waterhemp (Amaranthus tuberculatus). Missouri was the only state in our study region that had glyphosate-resistant weeds in 2005 (Fig. 2). By 2010, glyphosate-resistant weed species had been identified in South Dakota, Missouri, Illinois, lowa, and Kansas. The most resistant weed species were identified in South Dakota, where four glyphosate-resistant weed species were reported (common ragweed, horseweed, kochia, and tall waterhemp).

Table 2 provides descriptive statistics by weed management strategy. There are several notable trends. First, expenditures on herbicides increased over the course of the study period, perhaps because corn prices increased substantively. The most striking change was in expenditures on post-emergent herbicides by farmers that did not use glyphosate. These expenditures increased from $\$$ US $5.7 \mathrm{ha}^{-1}$ in 2005 to \$US $13.4 \mathrm{ha}^{-1}$ in 2010. Expenditures on post-emergent herbicides by farmers that did use glyphosate 
Table 4. Parameter estimates for the non-linear system of weed control costs and yields ${ }^{a}$

\begin{tabular}{|c|c|c|c|c|c|c|}
\hline & $\begin{array}{l}\text { Pre-emergent } \\
\text { weed pressure } \\
\qquad\left(W_{1}\right)\end{array}$ & $\begin{array}{l}\text { Post-emergent } \\
\text { weed pressure } \\
\qquad\left(W_{2}\right)\end{array}$ & $\begin{array}{l}\text { Weed-free } \\
\text { yields } \\
{[\ln (Y)]}\end{array}$ & $\begin{array}{l}\text { Efficacy of } \\
\text { pre-emergent } \\
\text { herbicides } \\
\left(c_{1}\right)\end{array}$ & $\begin{array}{c}\text { Efficacy of } \\
\text { post-emergent } \\
\text { glyphosate } \\
\left(c_{2}{ }^{g}\right)\end{array}$ & $\begin{array}{c}\text { Efficacy of } \\
\text { post-emergent } \\
\text { herbicides other } \\
\text { than glyphosate } \\
\left(c_{2}{ }^{n g}\right)\end{array}$ \\
\hline Intercept & $-3.42^{* * *}$ & $-4.89^{* *}$ & $5.39^{* * *}$ & $2.38^{* * *}$ & $3.89^{* * *}$ & $1.90^{* * *}$ \\
\hline $\begin{array}{l}\text { Cumulative growing season } \\
\text { GDDs, } 20 \text { year average }\end{array}$ & 0.93 & $2.50^{* * *}$ & $-0.65^{* * *}$ & & & \\
\hline $\begin{array}{l}\text { Cumulative growing season } \\
\text { precipitation, } 20 \text { year average }\end{array}$ & $-0.65^{*}$ & 0.57 & $0.09 *$ & & & \\
\hline $\mathrm{NCCPI}$ & 0.13 & 0.63 & $0.15^{* * *}$ & & & \\
\hline Heartland & -0.49 & -1.08 & $0.38^{* * *}$ & & & \\
\hline Northern Crescent & 0.36 & 0.31 & $0.28 * *$ & & & \\
\hline Northern Great Plains & -0.53 & -1.17 & $0.25^{*}$ & & & \\
\hline Prairie Gateway & 0.14 & -0.56 & $0.29 * *$ & & & \\
\hline Year 2010 & $-0.40^{*}$ & -0.49 & $0.04^{* *}$ & 0.01 & -0.05 & -0.36 \\
\hline Soil pH & & & & -0.04 & & \\
\hline Soil organic matter & & & & 0.05 & & \\
\hline HR seed adoption & & & & & 1.17 & \\
\hline $\begin{array}{l}\text { Number of weeds resistant to } \\
\text { glyphosate in state }\end{array}$ & & & & & -0.46 & \\
\hline $\begin{array}{l}\text { HR seed adoption } \times \text { number of } \\
\text { weeds resistant to glyphosate } \\
\text { in state }\end{array}$ & & & & & $-0.74^{*}$ & \\
\hline $\begin{array}{l}\text { Generalized residual for HR seed } \\
\text { use }\end{array}$ & $0.26^{*}$ & $0.25^{* *}$ & & & & \\
\hline $\begin{array}{l}\text { Generalized residual for logged } \\
\text { yield goals }\end{array}$ & $-1.81^{* * *}$ & & & & & \\
\hline \multicolumn{7}{|c|}{$\begin{array}{l}\text { a Asterisks } *{ }^{* *} \text {, and } * * * \text { denote } 10,5 \text {, and } 1 \% \text { levels of significance. Table entries are the means across the } B=300 \text { bootstrap samples. Standard errors } \\
\text { underlying statistical significance are calculated as the standard deviation of the parameter estimates across the bootstrap samples. Estimates are } \\
\text { robust to a wide range of starting values. These estimates are presented, along with standard errors and } 95 \% \text { confidence intervals, in supporting } \\
\text { information Appendix B. }\end{array}$} \\
\hline
\end{tabular}

Table 5. A comparison of field trials and model estimates: crop damage and control (on fields in HT production systems in the absence of glyphosate-resistant weeds) ${ }^{\mathrm{a}}$

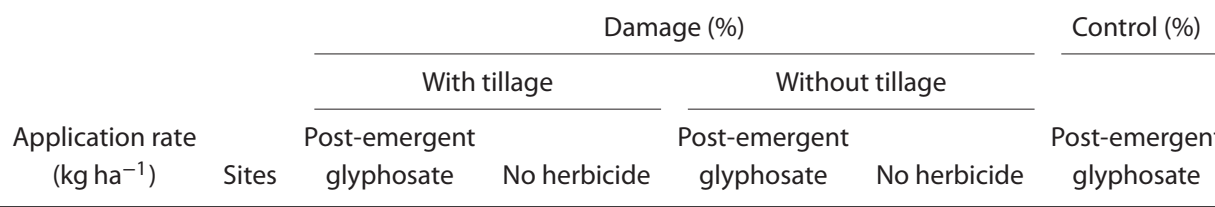

\section{Field trials}

Cox et al 32

Gower et al. ${ }^{38}$

Gower et al. ${ }^{36}$

Johnson et al. ${ }^{37}$

Norsworthy and Frederick ${ }^{35}$

Nurse et al. ${ }^{34}$

Tharp and Kells ${ }^{39}$

Thomas et al. ${ }^{33}$

Average

$\begin{array}{lccc}1.12 & 1 & 23 & 71 \\ 1.07 & 3 & 6 & 37 \\ 1.12 & 35 & 7 & 56 \\ 1.12 & 3 & 12 & 73 \\ 1.12 & 1 & 7 & 17 \\ 1.12 & 2 & 10 & 52 \\ 1.12 & 1 & 4 & 44 \\ 1.12 & 1 & 7 & 88 \\ & & 10 & 55\end{array}$

\section{1}

37

56

8

Model

Point estimate

$\begin{array}{cc}1.4 & 15 \\ 1-2 & 9-25\end{array}$

$3-6$

$22-63$

(Percentile-Based) Confidence interval

a Neither pre-emergent nor other post-emergent herbicides were applied during the "Post-emergent glyphosate" field trials reported in this table. 


\begin{tabular}{|lcr|}
\hline Table 6. Yield losses and damage & & \\
& 2005 & 2010 \\
\hline $\begin{array}{l}\text { Yield losses }\left(\mathbf{k g ~ h a}^{-1} \text { ) }\right. \\
\text { Without weed control }\end{array}$ & $4508^{* * *}$ & $3919^{* * *}$ \\
At observed levels of weed control & $794^{* * *}$ & $387^{* * *}$ \\
Damage (\% of weed-free yield) & $39^{* * *}$ & $32^{* *}$ \\
Without weed control & $7^{* * *}$ & $3^{* * *}$ \\
At observed levels of weed control & & \\
\hline a Asterisks ${ }^{* * *}$, and ${ }^{* * *}$ denote 10, 5, and 1\% levels of significance. \\
\hline
\end{tabular}

also increased over this time period, from \$US $8.1 \mathrm{ha}^{-1}$ in 2005 to \$US $9.3 \mathrm{ha}^{-1}$ in 2010 . Though a $\$ 1.2 \mathrm{ha}^{-1}$ increase may seem negligible, glyphosate prices fell by approximately $50 \%$ from 2005 to 2010, so this small increase in expenditures belies a large increase in glyphosate usage.

\section{RESULTS AND DISCUSSION}

Table 3 presents results for the first stage of our two-stage empirical model. We find that increases in soil organic matter and farm size tend to increase the probability of HR seed use. The NCCPI has a negative impact on HR seed use, perhaps because it is easier for corn to outcompete weeds on fields with highly productive soils. Surprisingly, the average price of an HR trait does not have a statistically significant impact on adoption decisions. It is possible that this is because state-level input and output prices are correlated. This correlation, which is often referred to as multicollinearity, can induce upward bias in estimates of the standard errors and complicate the interpretation of the parameter estimates of the collinear variables. ${ }^{30}$

We find that increases in soil productivity, farm size, and soil $\mathrm{pH}$ tend to increase yield goals. These results are not surprising given that corn grows best on fertile soils, that large farms tend to be more productive, and that nutrient availability is restricted in acidic soils. $^{31}$

Table 4 depicts how farm and field-level conditions affect pre-emergent weed pressure, post-emergent weed pressure, and weed-free yields. They also suggest how effective pre-emergent applications are relative to post-emergent ones. We find that soil productivity increases pre-emergent weed pressure, post-emergent weed pressure, and weed-free yields. Our estimates of weed-free yields were higher in states such as lowa and Illinois, where yield goals and abatement levels tended to be higher than average.

Notably, the generalized residuals for HR seed use and yield goals had a significant impact on both pre-emergent and post-emergent weed pressure. The parameter estimates suggest that latent weed pressure was systematically higher on fields where HR seeds were used and systematically lower on fields where yield goals were high, even after controlling for observable environmental conditions. In other words, failing to account for endogeneity would have biased the results of the analysis.

Our results are similar to those obtained in field trials (Table 5). ${ }^{32-37}$ For instance, Gower et al..$^{38}$ found that weeds damaged $37 \%$ of yields on tilled, untreated fields, but only $7 \%$ on fields that were treated with a post-emergent glyphosate application. Our analysis predicts crop damages of $15 \%$ and $1.4 \%$, respectively. Tharp and Kells ${ }^{39}$ found that weeds damaged $57 \%$

\begin{tabular}{|c|c|c|c|c|}
\hline & \multicolumn{2}{|c|}{$\begin{array}{l}\text { Fields with post-emergent } \\
\text { glyphosate application (\%) }\end{array}$} & \multicolumn{2}{|c|}{$\begin{array}{l}\text { Fields without post-emergent } \\
\text { glyphosate application (\%) }\end{array}$} \\
\hline & 2005 & 2010 & 2005 & 2010 \\
\hline By tillage and cultivation & $6^{* * *}$ & $3^{* * *}$ & $11^{* * *}$ & $5 * * *$ \\
\hline By tillage & $4^{* * *}$ & $2^{* * *}$ & $8^{* * *}$ & $5^{* * *}$ \\
\hline By cultivation & $1^{* * *}$ & $0.5^{*}$ & $1^{* * *}$ & $0.1^{*}$ \\
\hline By pre-emergent and post-emergent herbicides & $20^{* * *}$ & $19^{* *}$ & $10^{* * *}$ & $15^{* *}$ \\
\hline By pre-emergent herbicides & $3^{* * *}$ & $3^{* *}$ & $4^{* * *}$ & $4^{* * *}$ \\
\hline By post-emergent herbicides & $12^{* * *}$ & $10^{* *}$ & $5^{* * *}$ & $8^{* *}$ \\
\hline
\end{tabular}

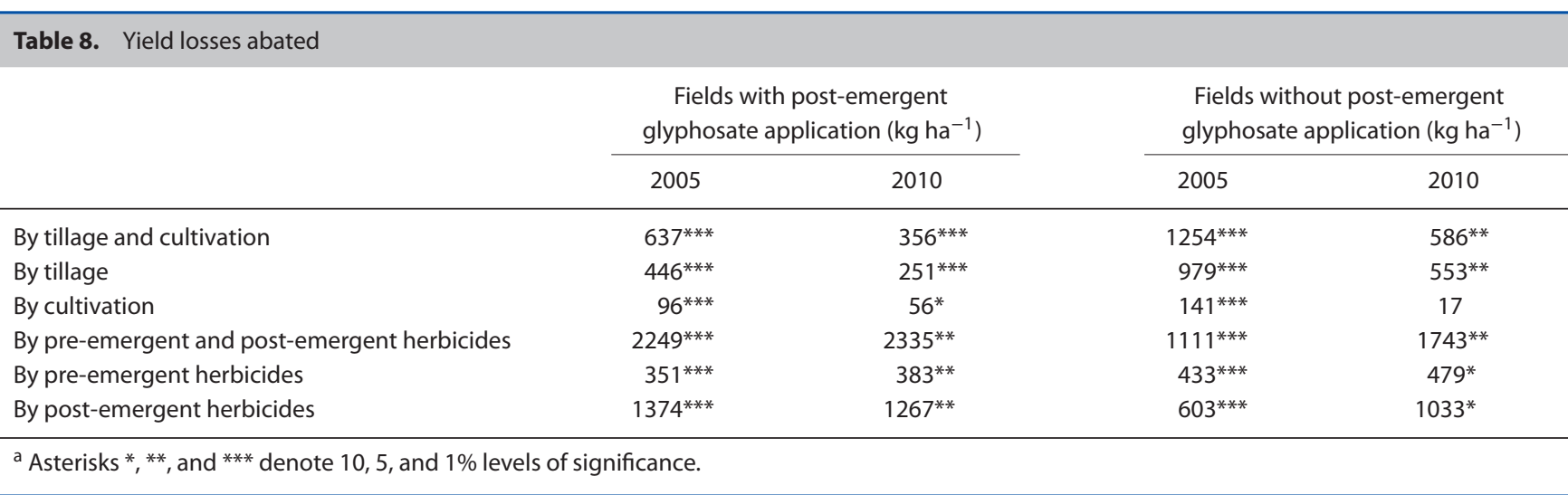


Table 9. Percentage of weeds controlled by post-emergent glyphosate applications (at the label rate) in HT production systems ${ }^{\mathrm{a}}$

\begin{tabular}{|c|c|c|c|c|}
\hline \multirow[b]{2}{*}{$\begin{array}{l}\text { Number of state-level } \\
\text { glyphosate-resistant weeds }\end{array}$} & \multirow[b]{2}{*}{$\begin{array}{l}\text { Average percentage of } \\
\text { weeds controlled }\end{array}$} & \multicolumn{3}{|c|}{ Impacts of resistance (\%) } \\
\hline & & 2.5th percentile & $\begin{array}{c}\text { Average of } \\
\text { bootstrapped } \\
\text { estimates }\end{array}$ & $\begin{array}{c}97.5 \text { th } \\
\text { percentile }\end{array}$ \\
\hline None & $98.9^{* * *}$ & & & \\
\hline One & $97.2^{* * *}$ & -0.04 & $-1.7^{*}$ & -3.7 \\
\hline Two & $91.7^{* * *}$ & -1.0 & $-7.2^{*}$ & -15.8 \\
\hline Three & $70.7^{* * *}$ & -1.7 & $-28.2^{*}$ & -61.0 \\
\hline Four ${ }^{b}$ & -17.9 & -2.5 & -116.8 & -232.2 \\
\hline
\end{tabular}

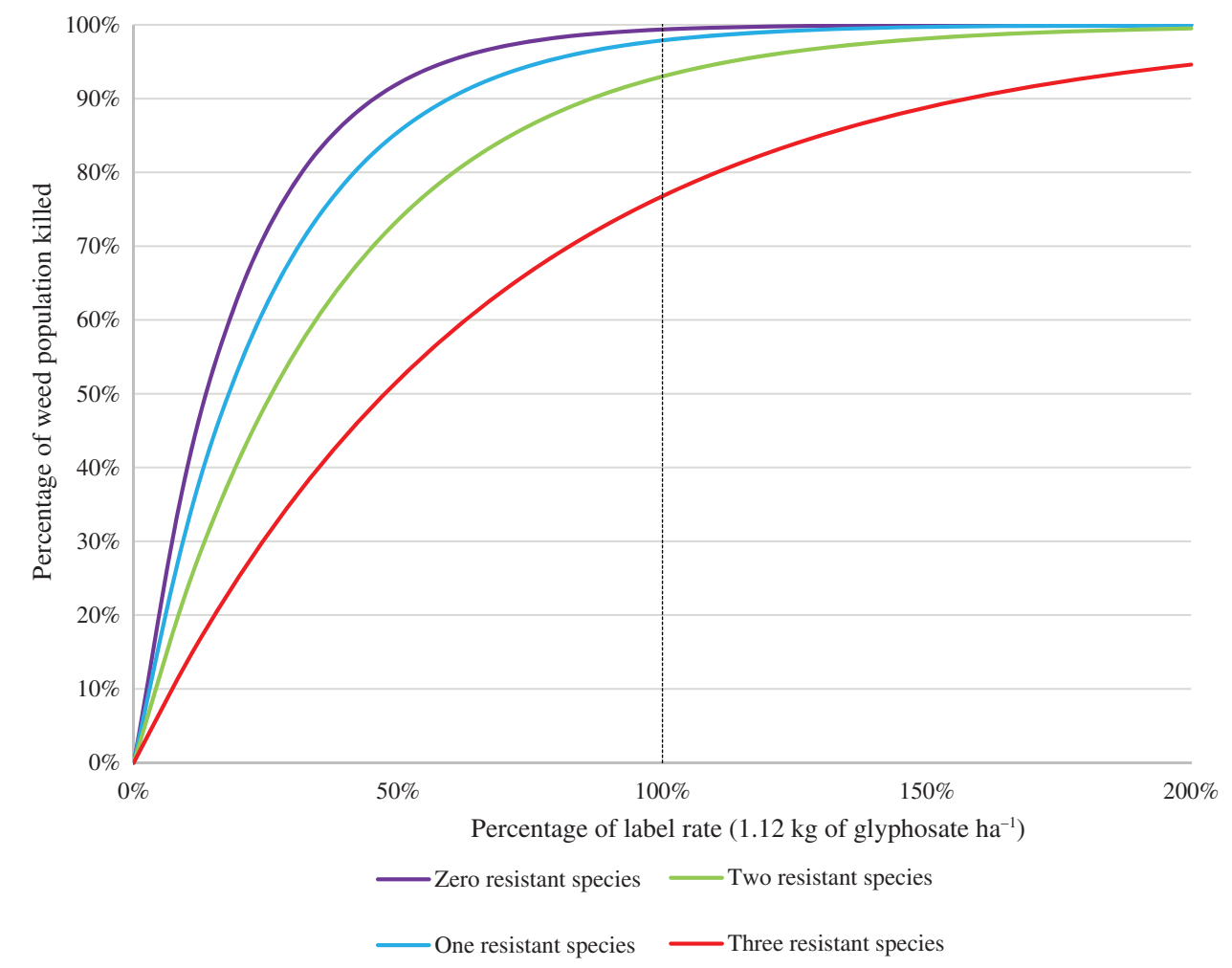

Figure 3. Average post-emergent weed control provided by glyphosate for US farmers who plant HR corn seeds, by number of glyphosate-resistant weed species.

of yields on untilled, untreated fields, but only $2 \%$ on fields that were treated with a post-emergent glyphosate application. Our analysis predicts $36 \%$ and $4 \%$, respectively.

Generally, we predict higher levels of control from post-emergent glyphosate applications and lower yield losses than most field trials. This is not surprising given that weed populations on university-affiliated sites tend to be higher than weed populations on commercial fields. ${ }^{36}$ Alternatively, it is possible that weed pressure was lower during our study period than in the years that the field trials were conducted.

As far as the efficacy of weed control is concerned, we find that post-emergent weed control was more effective for post-emergent glyphosate users than for other farmers $\left(c_{2}{ }^{g}>c_{2}{ }^{n g}\right)$, especially on fields in HR production systems (Table 4). Post-emergent weed control was more effective than pre-emergent control $\left(c_{2}{ }^{g}>c_{1}\right)$ for post-emergent glyphosate users but post-emergent control was less effective than pre-emergent control $\left(c_{2}{ }^{n g}<c_{1}\right)$ for other farmers.

Assuming that farmers did not control weed infestations, we predict that weeds would have caused average yield losses of approximately $4500 \mathrm{~kg} \mathrm{ha}^{-1}$ (39\% of weed-free yields) in 2005 and $3900 \mathrm{~kg} \mathrm{ha}^{-1}$ (32\% of weed-free yields) in 2010 (Table 6). Given farmers' pre-emergent and post-emergent expenditures on weed control, we predict average yield losses of approximately $800 \mathrm{~kg} \mathrm{ha}^{-1}(7 \%)$ in 2005 and $400 \mathrm{~kg} \mathrm{ha}^{-1}$ (3\%) in 2010. This implies that weed control increased the yields of farmers in our sample by an average of approximately $3700 \mathrm{~kg} \mathrm{ha}^{-1}$ (worth \$US $255 \mathrm{ha}^{-1}$ ) in 2005 and an average of approximately $3500 \mathrm{~kg} \mathrm{ha}^{-1}$ (worth \$US $575 \mathrm{ha}^{-1}$ ) in 2010.

Our results suggest that farmers who used glyphosate in post-emergent herbicide applications obtained the vast majority of their weed control from chemical applications (Tables 7 and 8). 
On average, these farmers reduced their yield losses by $2249 \mathrm{~kg} \mathrm{ha}^{-1}$ by using herbicides in 2005 and by $2335 \mathrm{~kg} \mathrm{ha}^{-1}$ by using herbicides in 2010. Most of this weed control was obtained via post-emergent applications, which reduced damage from weeds by $12 \%$ in 2005 and by $10 \%$ in 2010 .

Farmers who did not use glyphosate in post-emergent herbicide applications obtained most of their weed control from tillage in 2005 but relied heavily on post-emergent herbicides in 2010. It is unclear what drove this trend. One explanation is that increasing corn prices raised the optimal level of weed control throughout the 2010 growing season. Because these price increases occurred after pre-emergent weed control decisions had been made farmers increased their post-emergent herbicide usage.

Our results suggest that glyphosate kills approximately $99 \%$ of weeds, on average, when applied at the label rate $(1.12 \mathrm{~kg}$ glyphosate ha ${ }^{-1}$ ) in HR production systems if glyphosate-resistant weeds are not present (Table 9). Not surprisingly, the efficacy of glyphosate applications is lower when glyphosate-resistant weeds are present (Fig. 3). The magnitude of this effect is fairly small when small numbers of glyphosate-resistant weed species are present (the presence of one glyphosate-resistant weed species reduces control by approximately two percentage points at the label rate). However, the presence of three or more glyphosate-resistant weed species reduces control by over 30 percentage points.

Generally, these results should be interpreted with caution. While resistance tends to be localized, our measure of resistance is a state-level variable. Even if glyphosate's efficacy is very low on fields where weed resistance has developed, the average state-level impact will be small if resistance is uncommon. This suggests that our results may underestimate the impacts of glyphosate resistance on weed control.

\section{CONCLUSION}

This article studies glyphosate resistance in US corn production using a behavioral model of corn farmers' weed control decisions. It analyzes cross-sectional data from the USDA's 2005 and 2010 ARMS. Because we use a state-level variable as a proxy for glyphosate resistance, our estimates should be interpreted as state-level averages, not field-level impacts.

We found that the presence of one or two glyphosate-resistant weed species had a fairly small impact on control, but that the presence of multiple resistant weed species could decrease control by over 30 percentage points. Our findings also highlight differences in crop production technologies. Farmers who use glyphosate in post-emergent applications tend to get most of their weed control from glyphosate applications. Farmers who do not use glyphosate in post-emergent applications relied heavily on tillage for weed control in 2005 but on post-emergent herbicides in 2010.

To our knowledge, reliable field-level data on weed populations do not exist for U.S. crops. Collecting these data would be time-consuming and expensive. However, this task could become increasingly feasible as remote sensing and precision agriculture technologies mature. Future studies should attempt to identify good sources of field-level data. These data could improve the accuracy and representativeness of empirical studies of weed control.

\section{SUPPORTING INFORMATION}

Supporting information may be found in the online version of this article.

\section{REFERENCES}

1 Peterson G, The discovery and development of 2,4-D. Agric Hist 41:243-254 (1967).

2 Franz J, Mao M and Sikorski J, Glyphosate: A Unique and Global Herbicide. ACS Monograph No. 189, American Chemical Society, Washington, DC (1997).

3 Adoption of Genetically Engineered Crops in the U.S. [Online]. US Department of Agriculture - Economic Research Service, Washington, DC (2016). Available: http://www.ers.usda.gov/data-products/ adoption-of-genetically-engineered-crops-in-the-us/recenttrends-in-ge-adoption.aspx [2 June 2017].

4 Quick Stats. [Online]. US Department of Agriculture - National Agricultural Statistics Service, Washington, DC (2015). Available: http:// www.nass.usda.gov/Quick_Stats [2 June 2017].

5 Livingston M, Fernandez-Cornejo J, Unger J, Osteen C, Schimmelpfennig D, Park T et al., The economics of glyphosate resistance management in corn and soybean production. Economic Research Report No. 184, US Department of Agriculture-Economic Research Service, Washington, DC (2015).

6 Heap I, The International Survey of Herbicide Resistant Weeds [Online]. WeedScience (2016). Available: http://www.weedscience.org/ summary/home.aspx [2 June 2017].

7 Lichtenberg $E$ and Zilberman D, The economics of damage control: why specification matters. Am J Agric Econ 68:261 - 273 (1986).

8 lowa Farm and Rural Life Poll: Farmer Perspectives on Pesticide Resistance [Online]. lowa State University Extension and Outreach, Ames, IA (2014). Available: https://store.extension.iastate.edu/Product/ lowa-Farm-and-Rural-Life-Poll-Farmer-Perspectives-on-PesticideResistance [11 March 2016].

9 Saha A, Shumway Rand Havenner A, The economics and econometrics of damage control. Am J Agric Econ 79:773-785 (1997).

10 Chambers $R$ and Lichtenberg $E$, Simple econometrics of pesticide productivity. Am J Agric Econ 76:407-417 (1994).

11 Chambers R and Tzouvelekas V, Estimating population dynamics without population data. J Environ Econ Manag 66:510-522 (2013).

12 Fernandez-Cornejo J, Klotz-Ingram C and Jans S, Farm-level effects of adopting herbicide-tolerant soybeans in the U.S.A.J Agric Appl Econ 34:149-163 (2002).

13 Fernandez-Cornejo J, Hendricks C and Mishra A, Technology adoption and off-farm household income: the case of herbicide-tolerant soybeans. J Agric Appl Econ 37:549-563 (2005).

14 Nolan $E$ and Santos $P$, The contribution of genetic modification to changes in corn yield in the United States. Am J Agric Econ 94:1171-1188 (2012).

15 Fox $G$ and Weersink A, Damage control and increasing returns. Am J Agric Econ 77:33-39 (1995).

16 Evans S, Knezevic S, Lindquist J, Shapiro C and Blankenship E, Nitrogen application influences the critical period for weed control in corn. Weed Sci 51:408-417 (2003).

17 Hall M, Swanton C and Anderson G, The critical period of weed control in grain corn (Zea mays). Weed Sci 40:441 - 447 (1992).

18 Amemiya T, The maximum likelihood and the nonlinear three-stage least squares estimator in the general nonlinear simultaneous equation model. Econometrica 45:955-968 (1977).

19 Amemiya T, Advanced Econometrics. Harvard University Press, Cambridge, MA (1985).

20 Loux M, Doohan D, Dobbels A, Johnson W, Young B, Legleiter T et al., Weed Control Guide for Ohio, Indiana, and Illinois [Online]. Ohio State University Extension, Columbus, OH (2015). Available: http://bulletin.ipm.illinois.edu/wp-content/uploads/2014/12/ 2015-Weed-Control-Guide.pdf [2 June 2017].

21 Wooldridge J, Quasi-maximum likelihood estimation and testing for nonlinear models with endogenous explanatory variables. J Econometrics 182:226-234 (2014).

22 Wooldridge J, Control function methods in applied econometrics. J Hum Resour 50:420-445 (2015).

23 Terza J, Basu A and Rathouz P, Two-stage residual inclusion estimation: addressing endogeneity in health econometric modeling. J Hlth Econ 27:531-543 (2008).

24 Goodwin B and Mishra A, Are 'decoupled' farm program payments really decoupled? An empirical investigation. Am J Agric Econ 88:73-89 (2006).

25 Pagan A, Econometric issues in the analysis of regressions with generated regressors. Int Econ Rev 25:221 -247 (1984).

26 Yen $\mathrm{S}$ and Lin B, Beverage consumption among US children and adolescents: full-information and quasi maximum-likelihood 
estimation of a censored system. Eur Rev Agric Econ 29:85-103 (2002).

27 ARMS Farm Financial and Crop Production Practices Documentation [Online]. US Department of Agriculture - Economic Research Service, Washington, DC (2016). Available: https://www.ers.usda .gov/data-products/arms-farm-financial-and-crop-productionpractices/documentation/ [2 June 2017].

28 Commodity Costs and Returns [Online]. US Department of Agriculture - Economic Research Service, Washington, DC (2016). Available: http://www.ers.usda.gov/data-products/commoditycosts-and-returns.aspx [2 June 2017].

29 Dobos R, Sinclair H, Jr, and Robotham M, User Guide for the National Commodity Crop Productivity Index [Online]. US Department of Agriculture - National Resources Conservation Service, Washington, DC (2012). Available: https://www.nrcs.usda.gov/wps/PA NRCSConsumption/download?cid=nrcs142p2_050734\&ext=pdf [2 June 2017].

30 Belsley D, Kuh E and Welsh R, Regression Diagnostics Identifying Influential Data and Sources of Collinearity. John Wiley and Sons Inc, Cambridge, MA (1980).

31 Heggenstaller A, Crop Insights: Managing Soil pH for Crop Production [Online]. Pioneer (2012). Available: https://www .pioneer.com/home/site/us/agronomy/library/managing-soil-pH [2 June 2017].

32 Cox W, Hahn R and Stachowski P, Time of weed removal with glyphosate affects corn growth and yield components. Agron J 98:349-353 (2006).
33 Thomas W, Burke I and Wilcut J, Weed management in glyphosateresistant corn with glyphosate, halosulfuron, and mesotrione. Weed Technol 18:826-834 (2004)

34 Nurse R, Swanton C, Tardif F and Sikkema P, Weed control and yield are improved when glyphosate is preceded by a residual herbicide in glyphosate-tolerant maize (Zea mays). Crop Prot 25:1174-1179 (2006).

35 Norsworthy J and Frederick J, Integrated weed management strategies for maize (Zea mays) production on the southeastern coastal plains of North America. Crop Prot 24:119-126 (2005).

36 Gower S, Loux M, Cardina J, Harrison S, Sprankle P, Probst N et al., Effect of postemergence glyphosate application timing on weed control and grain yield in glyphosate-resistant corn: results of a 2-yr multistate study. Weed Technol 17:821-828 (2003).

37 Johnson W, Bradley P, Hart S, Buesinger M and Massey R, Efficacy and economics of weed management in glyphosate-resistant corn (Zea mays). Weed Technol 14:57-65 (2000).

38 Gower S, Loux M, Cardina J and Harrison S, Effect of planting date, residual herbicide, and postemergence application timing on weed control and grain yield in glyphosate-tolerant corn (Zea mays). Weed Technol 16:488-494 (2002).

39 Tharp B and Kells J, Influence of herbicide application rate, timing, and interrow cultivation on weed control and corn (Zea mays) yield in glufosinate-resistant and glyphosate-resistant corn. Weed Technol 13:807-813 (1999). 